International Journal of Social Science and Economic Research

ISSN: 2455-8834

Volume:06, Issue:04 "April 2021"

\title{
INDIA'S PROGRESSIVE TRANSITION TOWARDS A CASHLESS PAYMENT POLICY
}

\author{
ANANDI SAXENA \\ Jesus and Mary College, University of Delhi, New Delhi, India \\ DOI: 10.46609/IJSSER.2021.v06i04.013 URL: https://doi.org/10.46609/IJSSER.2021.v06i04.013
}

\begin{abstract}
A cashless payment policy is a system wherein the bulk of the transactions are processed through digital modes. The world is moving from a cash to a cashless payment policy. The Indian economy too faced a massive upheaval after the demonetisation in 2016 in a bid to transform it into a cashless economy and uproot the corruption and black money flowing within the recesses of the system. This research paper aims to throw light on the basic concepts, modes of the digital economy and the various initiatives taken by the Indian government to create a cashless environment. The paper also examines the perspectives of people regarding the cashless economy including the difficulties faced by them, the ease of doing online payments and their expectations from a digital economy moving forward. This paper analyses a detailed and structured questionnaire duly filled in from the residents of New Delhi, India and analysed using the simple percentage method. Responses from respondents show that a cashless economy can help in curbing black money, fake currency, fighting against terrorism, reducing cash related robbery, and will help in facilitating India's economic growth. Major challenges that can hinder the implementation of the policy include cyber fraud, a high rural illiteracy rate, and a lack of transparency \& efficiency in a digital payment system. This study shows that the introduction of a cashless payment system, aided with proper policy measures including the setting up of POS terminals, digital literacy campaigns and safeguards against cyber frauds can aid in the growth and development of the Indian economy.
\end{abstract}

Keywords: cashless economy, cashless transactions, digital society, digitalisation, electronic payments.

\section{INTRODUCTION}

A cashless economy is defined as a situation in which credit cards, debit cards, e-wallets etc are used to replace the old and traditional ways of payment including hard cash, coins and payments in kind. A cashless economy does not imply the absence of cash, it simply means that the larger 
bulk of payments is initiated through digital methods. India's demonetisation in 2016 encouraged the use of digital methods by customers. It reduced the risk of theft and loss of money leading to risk-free transactions. A digital society paves the way for more employment opportunities and economic growth. In developed countries, residents mostly rely on digital transactions and ecommerce but in India, 98\% of total economic transactions by volume are carried through hard cash.

Table 1 shows the list of top cashless nations across the world:

TABLE-1

\begin{tabular}{|l|l|}
\hline Top Cashless Countries & \\
\hline Singapore & $61 \%$ \\
\hline Netherlands & $60 \%$ \\
\hline France & $59 \%$ \\
\hline Sweden & $59 \%$ \\
\hline Canada & $57 \%$ \\
\hline Belgium & $56 \%$ \\
\hline United Kingdom & $52 \%$ \\
\hline USA & $45 \%$ \\
\hline Australia & $35 \%$ \\
\hline Germany & $33 \%$ \\
\hline South Korea & $29 \%$ \\
\hline India & $\mathbf{2 \%}$ \\
\hline
\end{tabular}

Source: http://m.businesstoday.in/story/here-are-the-top-cashless-countries-in-theworld/1/241430.html

The most popular modes of online transactions include:

1) Cheques- This is the oldest and the most familiar method of cashless payment. Cheques are issued of a specific amount in the name of the payee and is deposited in the respective bank.

2) Online Transfer- NEFT or RTGS- Unlike cheques, this is the fastest method as it is done 
International Journal of Social Science and Economic Research

ISSN: 2455-8834

Volume:06, Issue:04 "April 2021"

using an internet facility. NEFT and RTGS are used for transferring funds between banks within a country. RTGS is one of the fastest methods of transferring money as the money is credited within 30 minutes in the receiver's bank account.

3) E-wallets - This is a fast-growing, popular method commonly used for shopping and quick transfers, PayPal, TransferWise, Skrill and PayTM are the most commonly used Ewallets. E-wallets are linked with credit or debit card using an E-wallet id.

4) Mobile wallet -This is a very convenient way of making small payments. Mobile wallets do not require linking a debit or credit card. Money is loaded in the wallet using Immediate Payment Service (IMPS). The most popular mobile wallets are MobiKwik, PayUmoney, Oxigen, etc.

5) Credit or Debit card- These are also used for making purchases but the availability of swipe machines (POS) is limited. The usage of plastic cards is on a rise in India. The amount of debit cards is growing at a faster rate than credit cards (RBR's Global Payment Cards Data and Forecasts to 2021 study).

(See Figure 1 in Appendix for the Total Value of Credit and Debit Card Transactions at POS in India, by month)

\section{The benefits of a Cashless Economy:}

1) A cashless payment policy enhances the ease of doing business and enables a more detailed record of transactions and payments. It allows for more transparency in business operations and money transfers which reduces tax avoidance and money laundering.

2) It also helps in curbing black money and the printing and circulation of fake currency. As a result, it reduces the real estate prices because a large bulk of the black money is invested in real estate.

3) A Cashless Economy also reduces the cost of banking services. It also improves monetary policy by managing inflation and increases the economic growth of a country.

4) Another benefit of a cashless economy is that it prevents cash related robberies and other cash-related crimes. It also enhances the user experience of shopping and doing online transactions.

\section{The downsides of a Cashless Economy}

1) About $90 \%$ of the population works in a rural workforce. It produces nearly half of the 
International Journal of Social Science and Economic Research

ISSN: 2455-8834

Volume:06, Issue:04 "April 2021"

output in the country, and it will not be easy for this sector to become cashless and forego the traditional methods of payment.

2) Massive digital illiteracy is a major hindrance to a cashless economy. There is a general preference for cash transactions in India and a large part of the population is outside the scope of credit cards, debit cards, e-wallets etc.

3) People face difficulties in making electronic payments even in metro cities because of poor network facilities. Service providers need to constantly invest in technology to improve security and ease of transaction. People will only shift when it's comparatively easier, certain and safe to make cashless transactions. Small retailers also don't have enough resources to invest in electronic payment infrastructure.

4) A lot of merchants and businessmen prefer not to keep records to avoid paying taxes and buyers also find cash payments more convenient.

Table 2 depicts the non-cash transactions for two financial years and the percentage increase in cashless transactions.

TABLE- 2

\begin{tabular}{|l|c|c|c|}
\hline & $\begin{array}{c}\mathbf{2 0 1 5 - 1 6} \\
\text { (volume in millions) }\end{array}$ & $\begin{array}{c}\mathbf{2 0 1 6 - 1 7} \\
\text { (volume in } \\
\text { millions) }\end{array}$ & $\begin{array}{c}\text { Percentage } \\
\text { increase }\end{array}$ \\
\hline RTGS & 98.34 & 107.86 & $9.68 \%$ \\
\hline Cheque Truncation & 958.39 & 1111.86 & $16.01 \%$ \\
\hline EFT/NEFT & 1252.88 & 1622.10 & $29.47 \%$ \\
\hline M-wallet & 603.98 & 1629.98 & $169.87 \%$ \\
\hline Mobile banking & 389.49 & 976.85 & $150.80 \%$ \\
\hline Cards & 10038.67 & 12055.87 & $20.09 \%$ \\
\hline
\end{tabular}

Source: RBI Bulletin 
International Journal of Social Science and Economic Research

ISSN: 2455-8834

Volume:06, Issue:04 "April 2021"

Mobile banking and M-wallet operations have multiplied by three times in the year 2016-17. The growth rate of RTGS is minimum as compared to the other digital methods. NEFT and cards have shown moderate growth in the year 2016-17 but they are more popular among customers.

\section{Initiatives taken by The Government to steer The Indian Economy towards Digitisation:}

1) The Central Government Petroleum PSUs now offers a discount at the rate of $0.75 \%$ of the sale price to customers on the purchase of petrol or diesel for making digital payments.

2) The government has announced to extend financial support through NABARD to eligible banks for deployment of two POS machines each in one lakh villages at primary cooperative societies, milk societies or agricultural input dealers.

3) RRBs have been directed by NABARD to issue 'Rupay Kisan Cards' to Kisan Credit Card holders to enable them to make paperless transactions.

4) Railways provide up to $0.50 \%$ discount for monthly or seasonal tickets to customers.

5) Free accidental insurance covers up to Rs.10 lakh to passengers buying online tickets.

6) Discount of $5 \%$ on digital payment of paid services offered by railways.

7) Incentive by public sector insurance companies in the form of discounts or credit up to $10 \%$ of the general insurance premium and $8 \%$ of life insurance premium if payment is made through cashless methods.

8) The government has instructed public sector banks not to charge more than Rs.100 per month as monthly rent for POS terminals from traders.

9) Service tax is waived on digital transactions up to Rs.2000.

10) Under section $44 A D$ of the Income Tax Act 1961, a lower tax rate is charged on digital turnover up to Rs. 2 crores for small businesses.

11) Transactions up to Rs.1000 made through IMPS, USSD and UPI systems are free from charges.

12) Oil Marketing Companies also give a discount of $5 \%$ to customers on every online LPG refill booking.

\section{LITERATURE REVIEW}




\section{International Journal of Social Science and Economic Research}

ISSN: $2455-8834$

Volume:06, Issue:04 "April 2021"

- Rashmi Gujrati in her research paper "India's march towards faceless, paperless, cashless economy" (2017) elaborated upon the types of cashless payments, the merits and challenges of a cashless economy. This paper also mentioned the threats to the digital economy and prerequisites for a paperless society especially in a volatile environment as the Indian economy.

- Rajwinder Kaur in her research paper "India's progressive transition to a cashless payment policy" (2017) elaborated upon the basic concepts, modes of the digital economy and the initiatives taken by the government to promote a cashless payment policy. The paper also examined the perspectives of people regarding the cashless economy and subsequently the various hurdles they had to face in the process of onlinetransactions.

- Piyush Thukral in his research paper, "Cash Lite India: Boon Or Bane?” (2017) concluded that there is a difference between cash lite and cashless economy. A cashless economy means the complete ban of cash transactions whereas a cash lite or less-cash economy is related to reducing the magnitude of paper transactions. He further suggested that replacing a cash-centric environment with a paperless economy will be advantageous but we need to overcome a lot of hurdles. The government's carrot and stick theory towards digital payments has not proved impactful; as cash is an inevitable part of the Indian economy. Dreams of digital society cannot be achieved overnight. The government would have to make continuous and sincere efforts to develop strategies to make India less reliant on paper currency.

- Sunita Avula in her research paper, "The Cashless Economy in India: Prospects and Challenges" (2017) elaborated upon the programs initiated by the Indian government to bring the economy on the track of digitalisation and incentives offered to the public to attract them towards digital transactions. Government should work on digital literacy, penetration of POS terminals and improved internet connectivity to make India a digital society. It suggested important policy solutions to work on digital literacy and the smooth transition to a ubiquitous cashless economy.

- The research paper by Moses-Ashike (2011) refers to how transactions and payments are affected in a cashless economy. Marco and Bandiera (2004) have argued that increased usage of cashless banking instruments strengthens monetary policy effectiveness and thatthe current level of e-money usage does not pose a threat to the stability of the financial system. However, it also concludes that central banks can lose control over monetary policy if the government does not run a responsible fiscal policy. According to a 2015 report by Price Water House Coopers, India's unbanked population was nearly 233 million. Even for people 
with access to banking, the ability to use their debit or credit cards is limited because there are only about 1.46 million points of sale which accept payments through cards.

\section{METHODOLOGY AND DATA}

- The data for this paper is collected from both primary sources and secondary sources. The primary source includes a structured questionnaire with a sample size of about 50 people, all were residents of New Delhi, India and were in the age group of 18-50 years. The questionnaire aimed to find out the ease of doing cashless payments and the hurdles they had to face in their everyday life because of the government's concentrated efforts towards a digitised economy. The secondary sources include journals, newspaper, magazines and online websites.

- The research is descriptive in nature and the study was done using the convenience sampling procedure. The number of people surveyed was 50 which represents a response rate of $50 \%$. The sample included both literate and illiterate people since they would have varying experiences in a digitised economy and their responses would determine the reliability of the survey. The data was collected using a questionnaire. The responses from the respondents were collected and analyzed using the simple percentage method to draw conclusions.

- Research tools and techniques: Likert scale and verbal frequency scale are used for data analysis.

IV. DATA ANALYSIS AND INTERPRETATION

TABLE-1: KNOWLEDGE OF A CASHLESS PAYMENT POLICY

\begin{tabular}{|l|c|c|c|}
\hline & & FREQUENCY & PERCENT \\
\hline Are you aware of India's plans & Strongly Agree & 21 & $42 \%$ \\
for the digitisation of the Indian & Agree & 24 & $48 \%$ \\
& Undecided & 2 & $4 \%$ \\
& Disagree & 3 & $6 \%$ \\
& Strongly disagree & 0 & $0 \%$ \\
& Total & 50 & $100 \%$ \\
\hline
\end{tabular}


International Journal of Social Science and Economic Research

ISSN: 2455-8834

Volume:06, Issue:04 "April 2021"

Should a cashless payment policy be introduced in India?

\begin{tabular}{|c|c|c|}
\hline Strongly Agree & 14 & $28 \%$ \\
\hline Agree & 13 & $26 \%$ \\
\hline Undecided & 9 & $18 \%$ \\
\hline Disagree & 8 & $16 \%$ \\
\hline Strongly disagree & 6 & $12 \%$ \\
\hline Total & 50 & $100 \%$ \\
\hline
\end{tabular}

The above table shows a high degree of awareness regarding India's cashless payment policy plans. Since this study takes into account both literate and illiterate population, it implies that the Digital India efforts have been reaching far and wide. About $80 \%$ of people are aware of The GOI's Digital India plans. 54\% of the respondents also agree about the introduction of a cashless payment policy in India. Though, $28 \%$ of the respondents seem to have some reservations about a cashless economy. It might be because of the lack of preparedness in the system, freedom to use cash, inadequate technology etc.

TABLE-2: OPINIONS ABOUT THE PERCEIVED BENEFITS OF A CASHLESS ECONOMY

\begin{tabular}{|l|c|c|c|}
\hline & & FREQUENCY & PERCENT \\
\hline Reducing the risk of fake & Strongly Agree & 20 & $40 \%$ \\
& Agree & 20 & $40 \%$ \\
& Undecided & 5 & $10 \%$ \\
& Disagree & 3 & $6 \%$ \\
& Strongly disagree & 2 & $4 \%$
\end{tabular}


International Journal of Social Science and Economic Research

ISSN: 2455-8834

Volume:06, Issue:04 "April 2021"

\begin{tabular}{|c|c|c|c|}
\hline & Total & 50 & $100 \%$ \\
\hline \multirow[t]{6}{*}{ Preventing money laundering } & Strongly Agree & 11 & $22 \%$ \\
\hline & Agree & 16 & $32 \%$ \\
\hline & Undecided & 10 & $20 \%$ \\
\hline & Disagree & 7 & $14 \%$ \\
\hline & Strongly disagree & 6 & $12 \%$ \\
\hline & & 50 & $100 \%$ \\
\hline \multirow[t]{6}{*}{ Reducing corruption } & Strongly Agree & 7 & $14 \%$ \\
\hline & Agree & 14 & $28 \%$ \\
\hline & Undecided & 11 & $22 \%$ \\
\hline & Disagree & 11 & $22 \%$ \\
\hline & Strongly disagree & 7 & $14 \%$ \\
\hline & Total & 50 & $100 \%$ \\
\hline \multirow[t]{6}{*}{ Stimulating economic growth } & Strongly Agree & 10 & $20 \%$ \\
\hline & Agree & 18 & $36 \%$ \\
\hline & Undecided & 15 & $30 \%$ \\
\hline & Disagree & 5 & $10 \%$ \\
\hline & Strongly disagree & 2 & $4 \%$ \\
\hline & Total & 50 & $100 \%$ \\
\hline
\end{tabular}

The above table shows that the respondents most strongly believe that a cashless economy would reduce the incidence of fake currency, about $80 \%$ of people have agreed to this. $54 \%$ of respondents believe that a cashless economy can reduce instances of money laundering and 56\% believe that it can help stimulate economic growth as money flowing through the system can easily be traced back and the money hidden in illegitimate areas will be freed up, encouraging economic growth. While $42 \%$ of the respondents believe that it can reduce corruption, $36 \%$ of the respondents have their reservation regarding this aspect. As a country long plagued by corruption, this is a legitimate concern. 
International Journal of Social Science and Economic Research

ISSN: 2455-8834

Volume:06, Issue:04 "April 2021"

TABLE-3: OPINIONS ABOUT THE PERCEIVED CHALLENGES OF A CASHLESS ECONOMY

\begin{tabular}{|c|c|c|c|}
\hline & & FREQUENCY & PERCENT \\
\hline Prone to Cyber Crime & $\begin{array}{c}\text { Strongly Agree } \\
\text { Agree } \\
\text { Undecided } \\
\text { Disagree } \\
\text { Strongly disagree } \\
\text { Total }\end{array}$ & $\begin{array}{c}10 \\
22 \\
10 \\
6 \\
2 \\
50\end{array}$ & $\begin{array}{l}20 \% \\
44 \% \\
20 \% \\
12 \% \\
4 \% \\
100 \%\end{array}$ \\
\hline Need for adequate literacy & $\begin{array}{c}\text { Strongly Agree } \\
\text { Agree } \\
\text { Undecided } \\
\text { Disagree } \\
\text { Strongly disagree } \\
\text { Total }\end{array}$ & $\begin{array}{c}10 \\
19 \\
13 \\
5 \\
3 \\
50\end{array}$ & $\begin{array}{l}20 \% \\
38 \% \\
26 \% \\
10 \% \\
6 \% \\
100 \%\end{array}$ \\
\hline $\begin{array}{l}\text { Transparency \& Efficiency in } \\
\text { E- payments }\end{array}$ & $\begin{array}{c}\text { Strongly Agree } \\
\text { Agree } \\
\text { Undecided } \\
\text { Disagree } \\
\text { Strongly disagree } \\
\text { Total }\end{array}$ & $\begin{array}{c}14 \\
13 \\
8 \\
12 \\
3 \\
50\end{array}$ & $\begin{array}{l}28 \% \\
26 \% \\
16 \% \\
24 \% \\
6 \% \\
100 \%\end{array}$ \\
\hline Increase in Internet fraud & $\begin{array}{c}\text { Strongly Agree } \\
\text { Agree } \\
\text { Undecided } \\
\text { Disagree } \\
\text { Strongly disagree }\end{array}$ & $\begin{array}{c}13 \\
15 \\
11 \\
9 \\
2\end{array}$ & $\begin{array}{l}26 \% \\
30 \% \\
22 \% \\
18 \% \\
4 \%\end{array}$ \\
\hline
\end{tabular}


International Journal of Social Science and Economic Research

ISSN: 2455-8834

Volume:06, Issue:04 "April 2021"

\begin{tabular}{|l|l|l|l|}
\hline & Total & 50 & $100 \%$ \\
\hline
\end{tabular}

The above table shows that there are some major hindrances which the respondents believe can come with the cashless economy. The foremost being the increased number of cybercrimes, $64 \%$ believe that cybercrime will hinder the free implementation of a cashless economy. 54\% of the respondents believe that there's a lack of transparency \& efficiency in the payment system.

Internet fraud is also a major problem to be tackled in the cashless economy as $56 \%$ of the respondents see exposure to fraudulent activities as a huge problem. $58 \%$ of the respondents also believe that a lack of digital illiteracy can prove to be an issue in the implementation of a cashless payment policy. Rural areas with low literacy levels and inadequate access to high tech and a stable internet connection should be the priority group to achieve the aim of a cashless economy.

\section{CONCLUSION AND THE WAY FORWARD}

A large informal group of people, which makes up the bulk of India's population is still heavily dependent on cash. Cash transactions still make up the bulk of their payments and in the Indian markets, cash is king. To promote digital payments, better internet connectivity, security and reliability along with digital literacy should be provided to people. People living in remote areas need to be incentivised to adopt digital means by education, setting up of POS terminals etc. After demonetisation, there was a sudden spike in digital transactions but it shrank as new notes became available in the market which shows hesitation on the part of the Indian public towards a cashless payment policy.

From the above analysis of the questionnaire, it also appears that a large proportion of the people agree with the government on the usefulness of a cashless payment policy as it can help fight corruption, money laundering and encourage economic growth but they're hesitant to adopt a cashless payment policy because of the rising incidents of cybercrime and internet fraud. Hence, the government will need to make concentrated efforts to shield the public from instances of online fraud and make digital payments convenient and accessible. For smooth implementation of a cashless payment policy in India, the following measures are recommended: The Government needs to bring transparency and efficiency in the e-payment system, strategies which can be used by the government and RBI include, encouraging cashless transactions by licensing payment banks, promoting mobile wallets and withdrawing service charge on cards and digital payments. A financial literacy campaign should be conducted by the government to make the people aware of the benefits of digital payments and promote digital literacy amongst rural areas. 
International Journal of Social Science and Economic Research

ISSN: 2455-8834

Volume:06, Issue:04 "April 2021"

Concentrated and coordinated efforts by the government and the public can make the dream of a Digital India come to life.

\section{REFERENCES}

Akinola, O.S. (2012, August). Cashless Society, Problems and Prospects, Data Mining Research Potentials. International Journal of Computer Science and Telecommunications 03 (08) 49-55.

Avula, S. (2017, September). The Cashless Economy in India: Prospects and Challenges. International Journal of Research in Management Studies, 02 (09), 14-19. ISSN: 2455-7595

Gujrati, R. (2017, June). India's march towards a faceless, paperless, cashless economy. International Journal of Commerce and Management Research, 03 (06), 73-77. ISSN: 24551627

Mitra, A., Rath, S \& Nayank, J. K. (2017, July). Impact of Demonetisation on Cashless Transaction. International Journal of Engineering and Management Invention, 02 (03), 246- 251.

Shendge, P.A., Shelar, B.G \& Kapase, S. S. (2017, April). Impact and Importance of Cashless Transaction in India. International Journal of Current Trends in Engineering and Research, 03 (04), 22-28. ISSN: 2455-1392

Thukral, P. (2017, June). Cash Lite India: Boon Or Bane? International Journal of Innovative Research and Advanced Studies, 04 (06), 450-453. ISSN: 23944404

Lee, Jinkook, Fahzy Abdul-Rahman, and Hyungsoo Kim. "Debit card usage: an examination of its impact on household debt. Financial Services Review.16.1 (2007): 73.

More wedge, C. K., Holtzman, L., \& Epley, N. (2007). Unfixed resources: perceived costs, consumption, and the accessible account effect. Journal of Consumer Research, 34(4), 459467).

Marco, A. \& L.Bandiera (2004): -Monetary Policy, Monetary Areas and Financial Development with Electronic Money, IMF Working Study, IMF.

Moses-Ashike, H. (2011), -Cashless Economic can Reduce Risk of Carrying Huge Cashl, [Online]

Roth, B. L. (2010).-The Future of Money: The Cashless Economy - Part 1\|. [Online] Available: https://www.x.com/.../futuremoney-cashless-economy_part-i. 
International Journal of Social Science and Economic Research

ISSN: 2455-8834

Volume:06, Issue:04 "April 2021"

Woodford M. (2003). - Interest \& Price: Foundation of a Theory of Monetary Policyll, Princeton University Press.

\section{APPENDIX}

FIGURE 1: Total Value of Credit and Debit Card Transactions at POS in India, by month.

\section{Total Value of Credit and Debit Card Transactions at POS in India, by Month}

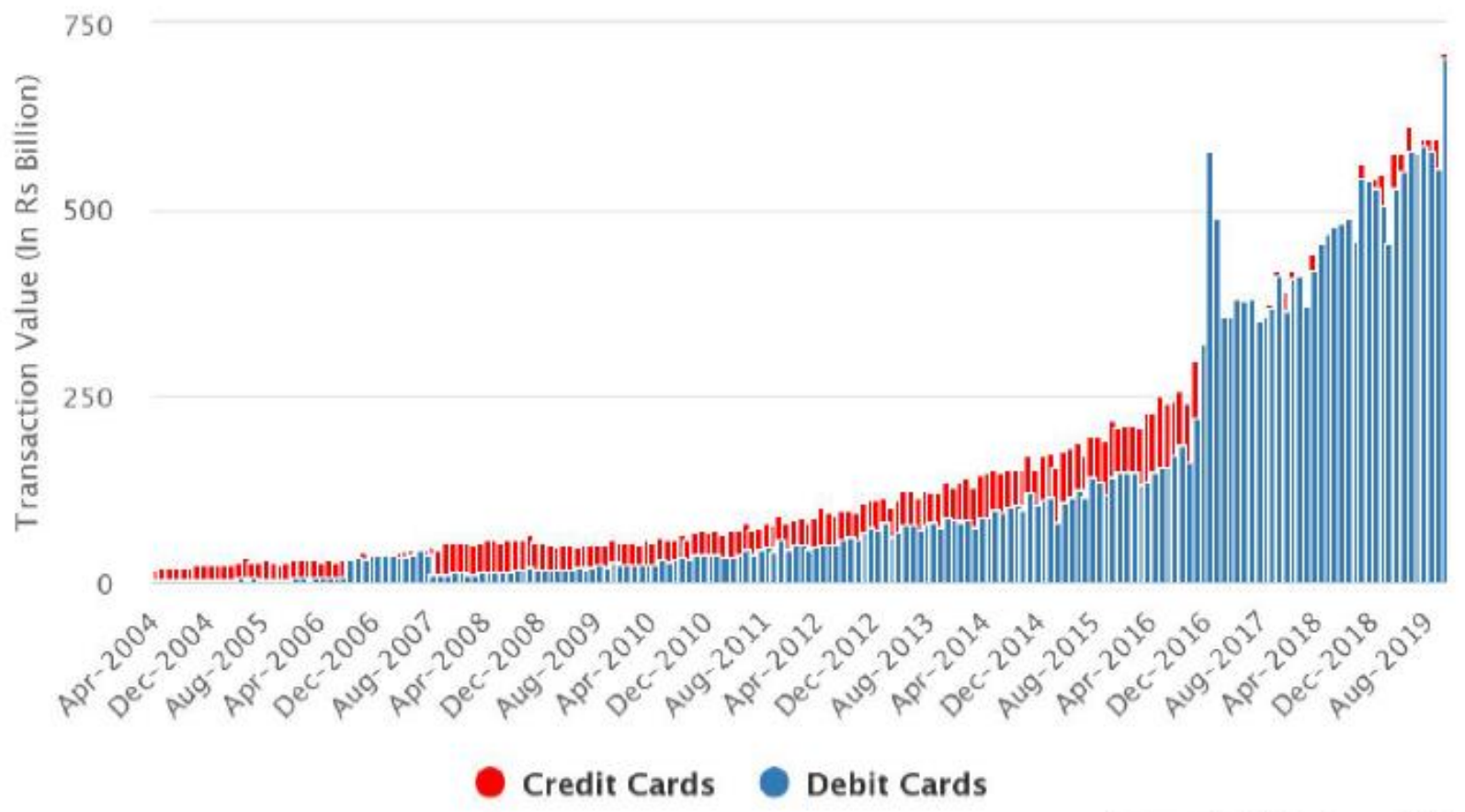

Source: https://dazeinfo.com/2019/09/17/total-value-of-credit-debit-card-transactions-at-posindia-by-month-graphfarm/

The number of transactions by debit card was recorded much higher from December 2016 to December 2017. Before demonetisation (2016), both credit and debit card utilisation showed steady growth. Post- Demonetisation brought a drastic rise in debit cards used during the month of December 2016. Card usage was maximum in the months of November and December but there was a sharp decline in the months of January and February 2017. Post-2017, both debit cards and credit cards have shown a steady rise. 